\title{
Türkiye'de Cari Açığı Etkileyen Faktörlerin Belirlenmesine Yönelik İstatistiksel Bir Araştırma
}

\author{
Serpil KILIÇ DEPREN*
}

\section{Öz}

Türk ekonomisinde son yıllarda büyüme ve gelişme yaşanmıştır. Ancak buna rağmen bazı alanlarda yeterince gelişme sağlanamamıştır. Özellikle çift hanelerde gerçekleșen enflasyon ve faizler bu alanlardan bazılarıdır. Gelișim sağlanamayan bir diğer önemli alan ise cari açıtır. Dolayısı ile küresel ekonomiler arasında ilk 10 içinde yer almak isteyen Türkiye'nin cari açık sorununu çözmesi gerekmektedir. Türkiye'de cari açığın çözümüne yönelik tedbirlerin alınabilmesi için öncelikle cari açığa neden olan faktörler belirlenmelidir. Çalışmada Türkiye'de cari açığı etkileyen faktörlerin belirlenmesi için Ocak 2006 ila Haziran 2018 arasındaki dönemdeki üçer aylık veriler dikkate alınmıştır. 11 adet makroekonomik gösterge ile Çok Değişkenli Uyarlanabilir Regresyon Uzanımları (Multivariate Adaptive Regression Splines: MARS) yöntemi uygulanmıştır. Çalışma sonucunda Türkiye'de ekonomik büyümenin, EUR TL kurunun, USD TL kurunun, ihtiyaç kredisi faizinin, taşıt kredisi faizinin ve enflasyonun (TÜFE) cari açığı etkilediği belirlenmiştir. Türkiye'de cari açığın düşürülmesi için söz konusu makroekonomik faktörlerin yakından izlenmesi ve cari açık üzerindeki olumsuz etkilerinin azaltılmasına yönelik düzenlemeler yapılması önerilmektedir.

Anahtar Kelimeler: Cari açık, Makroekonomik faktörler, Çok Değișkenli Uyarlanabilir Regresyon Uzanımları, MARS, Türkiye

JEL Sinıflandırmasi: C22, F32, F42.

\section{A Statistical Research upon Determining Factors Affecting Current Deficit in Turkey}

\begin{abstract}
Growth and development have been shown in the Turkish economy in recent years. However, enough development could not be provided in some areas. High inflation and interest rates, which are particularly at the level of double-digit, are some of these areas. One another important area is the current deficit. Therefore, Turkey, which wants to be among the top 10 economies in global economies, should resolve the current deficit problem. Causing factors to current deficit should be determined firstly in order to be able to resolve the current deficit problem in Turkey. In the study, quarterly data for the period between January 2006 and June 2018 are taken into consideration. Multivariate Adaptive Regression Splines (MARS) method with 11 macroeconomic variables was used in order to determine factors affecting the current deficit in Turkey. As a result of this study, it was determined that economic growth, EUR TL foreign exchange rate, USD TL foreign

\footnotetext{
Özgün Araştırma Makalesi (Original Research Article)

Geliş/Received: 28.02.2019

Kabul/Accepted: 24.05 .2021

DOI: https://dx.doi.org/10.17336/igusbd.533434

* Doç. Dr., Yıldız Teknik Üniversitesi, Fen Edebiyat Fakültesi, İstatistik Bölümü, İstanbul, Türkiye, E-posta: serkilic@yildiz.edu.tr ORCID https://orcid.org/0000-0003-4737-7131
} 
exchange rate, the interest rate for consumer credits and vehicle credits and inflation (CPI) affect current deficit in Turkey. It is recommended that affecting factors should be monitored closely in order to decrease the current deficit in Turkey and regulations should be made in order to decrease the negative effects of the current deficit.

Keywords: Current Deficit, Macroeconomic Factors, Multivariate Adaptive Regression Splines, MARS, Turkey

JEL Classification: C22, F32, F42.

\section{Giriş}

Türkiye'de 2002 yılı sonrasındaki süreçte, başta yüksek enflasyonun ve faizlerin düşürülmesi olmak üzere birçok ekonomik göstergede iyileşme yaşanmıștır. Bununla birlikte enflasyon, faiz ve işsizliğin çift hanelerde olması gibi sorunlar halen devam etmektedir. Diğer taraftan döviz kurlarında dalgalanmalar yaşanmakta olup ekonomide kırılganlığa ve ekonomik aktörler nezdinde olumsuzluklara neden olmaktadır. Bunlara ek olarak cari açılk Türkiye'nin uzun süredir yumuşak karnı olma özelliğini sürdürmektedir.

Cari açık, ödemeler bilançosunun bir alt bölümü olan cari işlemler hesabının negatif olma durumudur. Cari işlemler kapsamında ülkelere ait mal ve hizmet ticaretleri yer almaktadır. Bu yüzden ülkelerin gerçekleştirdikleri mal ve hizmet ithalatları sonucu ödediği dövizlerin, mal ve hizmet ihracatları sonucu kazandıkları dövizlerden fazla olması, ülkede cari açık oluşmasına neden olmaktadır (Eğilmez ve Kumcu, 2004, s. 350). Daha kapsamlı bakıldığında ise cari açık, dış ticaret dengesi, hizmetler dengesi, birincil gelir dengesi ve ikincil gelir dengesi toplamları sonucu ortaya çıkmaktadır. Birincil gelir dengesi, ücret ödemeleri, yatırım gelirleri, diğer yatırımlara ilişkin gelirleri içerirken ikincil gelir dengesi ise genel hükümet ile diğer sektörlere ilişkin gelirleri kapsamaktadır (TCMB, 2020). Dolayısıyla, dıș dünya ile yapılan mal ve hizmet ithalatı ve ihracatının yanı sıra söz konusu gelirler de cari açığın oluşması veya oluşacak cari açığın düzeyi üzerinde etki yapabilmektedir.

Ülkelerde cari açık oluştuğunda, söz konusu açık yabancı yatırım girişleri veya mevcut rezervlerden karşılanmaktadır. Bu kapsamda ülkelere gelen yatırımlar doğrudan yabancı yatırım veya portföy yatırımları olmaktadır. Yatırım türleri ekonomiler üzerinde farklı etkiler oluşturmaktadır. Bu durum ise ekonomilerde dalgalanmalara ve kırılganlıklara neden olmaktadır. Dolayısı ile sağlam ekonomiler için ülkelerin cari açık vermemesi esastır. Türkiye'de cari açığın gelişimine bakıldığında, yıllar itibari ile olumsuz bir seyir izlediği görülmektedir. Türkiye'de cari açı̆̆ın birikimli nominal gelişimine Tablo 1 'de yer verilmiştir.

Tablo 1: Türkiye'de Cari Açığın Yıllara Göre Gelişimi (Milyon ABD Doları)

\begin{tabular}{|l|l|l|l|l|l|l|l|}
\hline Yll & Cari Açık & Yıl & Cari Açık & Yll & Cari Açık & Yll & Cari Açık \\
\hline 1975 & -1.648 & 1986 & -1.465 & 1997 & -2.638 & 2008 & -39.425 \\
\hline 1976 & -2.029 & 1987 & -806 & 1998 & 2.000 & 2009 & -11.358 \\
\hline 1977 & -3.140 & 1988 & 1.596 & 1999 & -925 & 2010 & -44.616 \\
\hline 1978 & -1.265 & 1989 & 938 & 2000 & -9.920 & 2011 & -74.402 \\
\hline 1979 & -1.413 & 1990 & -2.625 & 2001 & 3.760 & 2012 & -47.963 \\
\hline 1980 & -3.408 & 1991 & 250 & 2002 & -626 & 2013 & -63.642 \\
\hline 1981 & -1.936 & 1992 & -974 & 2003 & -7.554 & 2014 & -43.644 \\
\hline 1982 & -952 & 1993 & -6.433 & 2004 & -14.198 & 2015 & -32.109 \\
\hline 1983 & -1.923 & 1994 & 2.631 & 2005 & -20.980 & 2016 & -33.137 \\
\hline 1984 & -1.439 & 1995 & -2.339 & 2006 & -31.168 & 2017 & -47.357 \\
\hline 1985 & -1.013 & 1996 & -2.437 & 2007 & -36.949 & $2018 / 8$ & -29.992 \\
\hline
\end{tabular}

Kaynak: Türkiye Cumhuriyet Merkez Bankası, 2018. 
Tablo 1'den görüleceği üzere, Türkiye'de cari açık 2002 yılı sonrasında ciddi tutarlara ulaşmış ve 2011 yılsonunda 74,4 milyar USD ile tarihi rekor kırmıştır. Diğer taraftan, ulusal veya küresel krizlerin yaşandığı 1994, 2001 ve 2009 yıllarında ya cari açık verilmemiş ya da cari açı negatif gerçekleşmiş ancak önceki yıllara kıyasla iyileşme görülerek cari açık tutarı küçülmüştür. Söz konusu durumun oluşmasında, kriz ortamında iç tüketimin azalmasına bağlı olarak ithalatta yaşanan gerileme, petrol fiyatlarında görülen gerileme, turizm gelirlerinde artış gibi sebepler yer almaktadır (Saçık ve Alagöz, 2010, s. 116; Yüksel, 2016, s. 104).

Güncel rakamlara bakıldığında ise 2017 yılsonunda 47,4 milyar USD seviyesinde olan cari açığın 2018 yılı Ağustos itibari ile 8 aylık dönemde 29,9 milyar USD seviyesinde gerçekleștiği görülmektedir.

Diğer taraftan, Türkiye'de cari açığın Gayri Safi Yurtiçi Hasıla'ya (GSYH) oranla gelişimine Şekil 1'de yer verilmiştir.

Şekil 1: Türkiye'de Cari Açı/GSYH Oranının Gelişimi (\%)

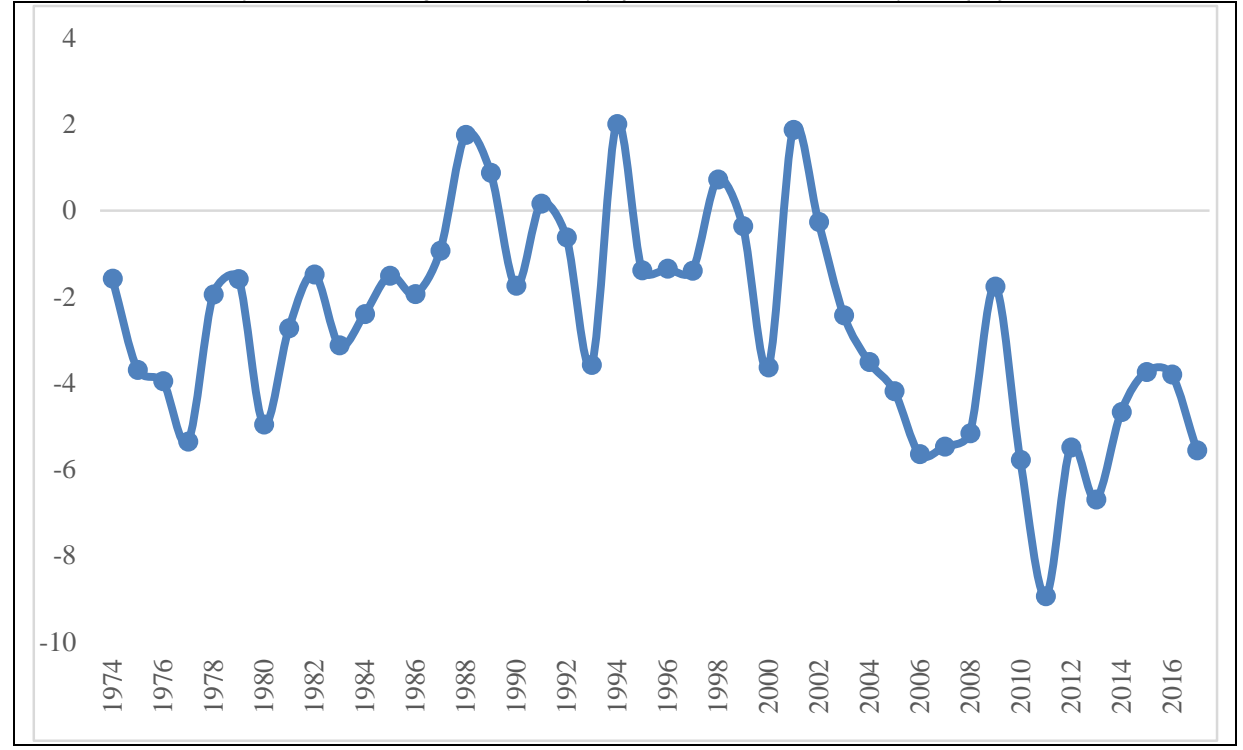

Kaynak: Dünya Bankası, 2018.

Şekil 1'den görüleceği üzere, 2002 yılı ve sonrasında cari açık/GSYH oranı hep negatif olarak gerçekleşmiștir. 2011 yılında cari açığın 74,4 milyar dolar ile tarihi rekorunu kırması üzerine, söz konusu oran da \%-9 ile en üst düzeye ulaşmıştır. Sonraki dönemlerde cari açı/GSYH oranında düşüş görülmekle birlikte cari açık verilmesine bağlı olarak hala negatif olarak seyretmektedir.

Türkiye ekonomisinin güçlendirilmesi ve büyümesine devam edebilmesi için paydaşlar açısından önem taşıyan cari açık sorunun çözülmesi gerekmektedir. Diğer taraftan cari açığın ulaştığı boyutlar Tablo 1 ve Şekil 1'de detaylı bir şekilde gösterilmiştir.

Türkiye'de cari açığın düşürülmesine yönelik ekonomi yönetimi tarafından çeşitli aksiyonlar alınmakta veya alınmakta olan aksiyonların cari açık üzerinde etkileri olmaktadır. Bu etkiler kimi zaman cari açığı azaltıcı kimi zaman ise arttırıcı etki yapmaktadır. Türkiye'de cari açık sorunun kalıcı bir şekilde çözülebilmesi için cari açığa yönelik yerinde müdahalelerin gerçekleștirilebilmesi bir gerekliliktir. $\mathrm{Bu}$ nedenle 
Türkiye'de cari açığı etkileyen faktörlerin belirlenmesi bir zorunluluktur. Bu çalışmada, Türkiye'de cari açığı etkileyen makroekonomik faktörlerin belirlenmesi amaçlanmıştır. Çalışmada cari açığı etkileyen faktörlerin belirlenmesi ve böylece cari açığın kontrol altında tutulmasına yönelik politika geliştirilmesine yardımcı olunması amaçlanmıştır.

Çalışma dört bölümden oluşmaktadır. İlk bölümde, çalışmanın amacı ve cari açık ile ilgili genel bilgiler verilmiştir. İkinci bölümde, cari açığın modellenmesi ile ilgili literatürde yer alan bazı çalışmalar incelenmiştir. Üçüncü bölümde, Türkiye'de cari açı̆̆ı etkileyen faktörlere yönelik analiz yapılarak araştırmanın sonuçları ele alınmıştır. Son bölümde ise elde edilen sonuçlar değerlendirilmiştir.

\section{Literatür Taraması} incelenmiştir.

Literatürdeki çalışmalar, uluslararası ve ulusal olmak üzere iki kısım halinde

\subsection{Uluslararası Çalışmalar}

Yurt dıșı literatürde cari açığı etkileyen faktörler ile ilgili yapılan çalışmalardan bazıları Tablo 2'de verilmiştir.

Tablo 2: Uluslararası Çalıșmalar

\begin{tabular}{|c|c|c|c|c|}
\hline Yazar & Yil & Ülke & Yöntem & Sonuç \\
\hline Karunartne & 1988 & Avustralya & Regresyon Analizi & $\begin{array}{l}\text { Büyüme oranı cari açı̆̆ın en önemli } \\
\text { sebebidir. }\end{array}$ \\
\hline $\begin{array}{l}\text { Nason ve } \\
\text { Rogers }\end{array}$ & 1999 & Kanada & $\begin{array}{l}\text { Vektör Otoregresif } \\
\text { Modeller (VAR) }\end{array}$ & $\begin{array}{l}\text { Bir önceki döneme ait cari açık, cari açığının } \\
\text { en önemli sebebidir. }\end{array}$ \\
\hline $\begin{array}{l}\text { Kandil ve } \\
\text { Greene }\end{array}$ & 2002 & $\mathrm{ABD}$ & Regresyon Analizi & $\begin{array}{l}\text { Büyüme oranı cari açığın en önemli sebebi } \\
\text { olarak bulunmaktadır. }\end{array}$ \\
\hline Bussiere vd. & 2004 & 33 OECD ülkesi & $\begin{array}{l}\text { Genelleştirilmiş } \\
\text { Momentler yöntemi } \\
(\mathrm{GMM})\end{array}$ & $\begin{array}{l}\text { Bir önceki döneme ait cari açık, cari açı̆̆ın } \\
\text { nedenidir. }\end{array}$ \\
\hline Aristovnik & 2007 & $\begin{array}{l}\text { Doğu Avrupa } \\
\text { ülkeleri }\end{array}$ & GMM & $\begin{array}{l}\text { Bütçe açı̆̆ı ve büyüme oranı, cari açığın } \\
\text { belirleyicileridir. }\end{array}$ \\
\hline Gülzar vd. & 2007 & Pakistan & Eşbütünleşme Analizi & $\begin{array}{l}\text { Tasarrufların düşüklüğü ve tüketimin } \\
\text { artması cari açığa neden olmaktadır. }\end{array}$ \\
\hline Bitzis vd. & 2008 & Yunanistan & Eşbütünleşme Analizi & $\begin{array}{l}\text { Faiz oranları ve döviz kurlarındaki } \\
\text { yükselişler cari açı̆ga sebep olmaktadır. }\end{array}$ \\
\hline Malik vd. & 2010 & Pakistan & $\begin{array}{l}\text { Eşbütünleşme ve } \\
\text { Nedensellik Analizi }\end{array}$ & $\begin{array}{l}\text { Ekonomik büyüme ile cari açıktaki azalma } \\
\text { arasında uzun vadede ilişki bulunmaktadır. }\end{array}$ \\
\hline Kaur vd. & 2012 & Hindistan & $\begin{array}{l}\text { Granger Nedensellik } \\
\text { Analizi }\end{array}$ & $\begin{array}{l}\text { Doğrudan yabancı yatırımlar ile cari açık } \\
\text { arasında tek yönlü nedensellik ilişkisi } \\
\text { bulunmaktadır. }\end{array}$ \\
\hline Agarwal & 2014 & Hindistan & $\begin{array}{l}\text { Granger Nedensellik } \\
\text { Analizi }\end{array}$ & Bütçe açığı cari açığa sebebiyet vermektedir. \\
\hline Mwangi & 2015 & Kenya & $\begin{array}{l}\text { Vektör Hata } \\
\text { Düzeltme Modeli } \\
\text { (VECM) }\end{array}$ & $\begin{array}{l}\text { Bütçe açığı ve ekonomik büyüme cari açı̆̆a } \\
\text { neden olmaktadır. }\end{array}$ \\
\hline $\begin{array}{l}\text { Fayaz ve } \\
\text { Sandeep }\end{array}$ & 2016 & Hindistan & VECM & $\begin{array}{l}\text { Net yabancı varlıklardaki artış cari açıkta } \\
\text { iyileşme sağlamaktadır. Ayrıca ithalattaki } \\
\text { artış cari açık üzerindeki baskıyı } \\
\text { artırmaktadır. }\end{array}$ \\
\hline $\begin{array}{l}\text { Banday ve } \\
\text { Aneja }\end{array}$ & 2016 & Hindistan & $\begin{array}{l}\text { Granger Nedensellik } \\
\text { Analizi }\end{array}$ & $\begin{array}{l}\text { Cari açık ile bütçe açığı arasında karşılıklı } \\
\text { nedensellik bulunmaktadır. Ayrıca döviz } \\
\text { kurları ve enflasyon cari açığı etkilemektedir. }\end{array}$ \\
\hline Çiğdem & 2017 & $\begin{array}{l}\text { Orta Doğu ve } \\
\text { Kuzey Afrika }\end{array}$ & Eşbütünleşme Analizi & $\begin{array}{l}\text { Tasarruflar cari açı̆̆ın oluşumunda önemli } \\
\text { bir faktördür. }\end{array}$ \\
\hline
\end{tabular}


Serpil Kılıç Depren, “Türkiye'de Cari Açı̆̆ı Etkileyen Faktörlerin Belirlenmesine Yönelik İstatistiksel Bir Araştırma”, İstanbul Gelişim Üniversitesi Sosyal Bilimler Dergisi, 8 (2), Ekim 2021, ss. 426-444.

\begin{tabular}{|l|l|l|l|l|}
\hline Yazar & Yıl & Ülke & Yöntem & Sonuç \\
\hline Longe vd. & 2018 & Nijerya & $\begin{array}{l}\text { Cari açlk üzerinde petrol fiyatları kısa } \\
\text { dönemde pozitif ama önemsiz; uzun } \\
\text { dönemde ise negatif ve önemli bir etki } \\
\text { oluşturmaktadır. }\end{array}$ \\
\hline Lin ve Kueh & 2019 & $\begin{array}{l}\text { Malezya, } \\
\text { Filipinler, } \\
\text { Singapur, } \\
\text { Tayland ve } \\
\text { Vietnam }\end{array}$ & $\begin{array}{l}\text { Panel Eşbütünleşme, } \\
\text { Panel Nedensellik }\end{array}$ & $\begin{array}{l}\text { Mali denge, kamu borcu ve reel GSYH ile cari } \\
\text { açlk arasında uzun dönemde eşbütünleşme } \\
\text { ve nedensellik bulunmaktadır. }\end{array}$ \\
\hline Soysa vd. & 2019 & Sri Lanka & $\begin{array}{l}\text { Johansen Nedensellik } \\
\text { Analizi, Hata } \\
\text { Düzeltme Modeli }\end{array}$ & $\begin{array}{l}\text { Petrol fiyatları ile cari açık arasında uzun } \\
\text { dönemde negatif bir ilişki bulunmaktadır. }\end{array}$ \\
\hline Han ve Yong & 2020 & Çin & Betimsel İstatistik & $\begin{array}{l}\text { Tasarruf-yatırım açı̆̆ının azalması ve reel } \\
\text { efektif döviz kurundaki değişiklikler, cari } \\
\text { açı̆̆ının azalmasının temel sebeplerindendir. }\end{array}$ \\
\hline $\begin{array}{l}\text { İmrohoroğlu } \\
\text { ve Zhao }\end{array}$ & 2020 & Çin & Zaman Serisi Analizi & $\begin{array}{l}\text { Hane halkı tasarruflarındaki görülen büyük } \\
\text { artışlar, cari fazla verilmesine neden } \\
\text { olmuştur. }\end{array}$ \\
\hline
\end{tabular}

\section{Kaynak: Yazarlar}

\subsection{Ulusal Çalışmalar}

Türkiye'de cari açığı etkileyen faktörler ile ilgili çalışmalar Tablo 3'te verilmiştir.

Tablo 3: Türkiye'de Yapılmıș Bazı Çalıșmalar

\begin{tabular}{|c|c|c|c|}
\hline Yazar & Yll & Yöntem & Sonuç \\
\hline Erbaykal & 2007 & VAR & $\begin{array}{l}\text { Ekonomik büyüme ve döviz } \\
\text { kurlarındaki değişiklikler cari açığa } \\
\text { sebebiyet vermektedir. }\end{array}$ \\
\hline Sever ve Demir & 2007 & $\begin{array}{l}\text { Granger Nedensellik } \\
\text { Analizi }\end{array}$ & $\begin{array}{l}\text { Bütçe açıkları cari açıı̆ın artmasına } \\
\text { neden olmaktadır. }\end{array}$ \\
\hline $\begin{array}{l}\text { Peker ve } \\
\text { Hotunluoğlu }\end{array}$ & 2009 & VAR & $\begin{array}{l}\text { Faiz oranlarındaki değişimler cari } \\
\text { açığın en önemli belirleyicisidir. }\end{array}$ \\
\hline Barışık ve Kesikoğlu & 2010 & $\begin{array}{l}\text { Granger Nedensellik } \\
\text { Analizi }\end{array}$ & $\begin{array}{l}\text { Cari açık ile bütçe açıı̆ı arasında çift } \\
\text { yönlü bir nedensellik ilişkisi } \\
\text { bulunmaktadır. }\end{array}$ \\
\hline $\begin{array}{l}\text { Bayraktutan ve } \\
\text { Demirtaş }\end{array}$ & 2011 & Panel Veri Analizi & $\begin{array}{l}\text { Büyüme oranları, yatırımlar ve bütçe } \\
\text { açı̆̆ı cari açık üzerinde etkili } \\
\text { olmaktadır. }\end{array}$ \\
\hline Doğru & 2012 & Korelasyon & $\begin{array}{l}\text { ABD ve AB'deki büyüme azaldıkça } \\
\text { Türkiye'de cari açı artmaktadır. }\end{array}$ \\
\hline Eşiyok & 2012 & Betimsel İstatistik & $\begin{array}{l}\text { Enerjide dışa bağımlılık ve enflasyon } \\
\text { hedeflemesi sonucunda ulusal paranın } \\
\text { aşırı değerlenmesi Türkiye'de cari açık } \\
\text { sorununu beslemektedir. }\end{array}$ \\
\hline $\begin{array}{l}\text { Yilmaz ve } \\
\text { Akıncl }\end{array}$ & 2012 & $\begin{array}{l}\text { Granger Nedensellik } \\
\text { Analizi }\end{array}$ & $\begin{array}{l}\text { Milli gelir, faiz oranları ve döviz kurları } \\
\text { cari açığı etkileyen önemli } \\
\text { bileșenlerdir. }\end{array}$ \\
\hline Çavdar ve Karaman & 2013 & $\begin{array}{l}\text { Granger Nedensellik } \\
\text { Analizi }\end{array}$ & $\begin{array}{l}\text { GSYH artışı ve devlet harcamaları cari } \\
\text { açık olușturmaktadır. }\end{array}$ \\
\hline Göçer & 2013 & VAR & $\begin{array}{l}\text { Enerji giderleri cari açığa neden } \\
\text { olmaktadır. }\end{array}$ \\
\hline Türkay & 2013 & $\begin{array}{l}\text { Granger Nedensellik } \\
\text { Analizi }\end{array}$ & $\begin{array}{l}\text { Cari açık ile bütçe açı̆̆ ve yatırım- } \\
\text { tasarruf açığı arasında uzun dönemli } \\
\text { ilișki bulunmaktadır. }\end{array}$ \\
\hline
\end{tabular}


Serpil Kılıç Depren, "Türkiye'de Cari Açı̆̆ı Etkileyen Faktörlerin Belirlenmesine Yönelik İstatistiksel Bir Araştırma", İstanbul Gelişim Üniversitesi Sosyal Bilimler Dergisi, 8 (2), Ekim 2021, ss. 426-444.

\begin{tabular}{|c|c|c|c|}
\hline Yazar & Yıl & Yöntem & Sonuç \\
\hline Ayhan & 2014 & $\begin{array}{l}\text { Granger Nedensellik } \\
\text { Analizi }\end{array}$ & $\begin{array}{l}\text { Brezilya, Rusya, Hindistan, Çin, Güney } \\
\text { Afrika ve Türkiye'de portföy girişleri } \\
\text { cari açığa neden olmaktadır. }\end{array}$ \\
\hline Çiftçi & 2014 & $\begin{array}{l}\text { Granger Nedensellik } \\
\text { Analizi }\end{array}$ & $\begin{array}{l}\text { Cari açık GSYH ve reel döviz } \\
\text { kurlarındaki değişime neden } \\
\text { olmaktadır. }\end{array}$ \\
\hline Doğan ve Bayraç & 2014 & VAR & $\begin{array}{l}\text { Türkiye'deki cari açık sürdürülebilir } \\
\text { değildir. }\end{array}$ \\
\hline $\begin{array}{l}\text { Yapar Saçık ve } \\
\text { Karaçayır }\end{array}$ & 2015 & ARDL Sinır Testi & $\begin{array}{l}\text { Cari açı̆̆ın azaltılmasında öncelikle } \\
\text { doğrudan yatırımlar sonrasında ise } \\
\text { portföy yatırımları önemlidir. }\end{array}$ \\
\hline Akıncı ve Yılmaz & 2016 & $\begin{array}{l}\text { Johansen Nedensellik } \\
\text { Analizi }\end{array}$ & $\begin{array}{l}\text { Cari açık ve faiz oranları arasında } \\
\text { istatistiksel açıdan önemli bir ilişki } \\
\text { bulunmaktadır. }\end{array}$ \\
\hline Dücan vd. & 2016 & VAR & $\begin{array}{l}\text { Tüketici kredilerindeki artış, cari açıkta } \\
\text { artıșa neden olmaktadır. }\end{array}$ \\
\hline Keskingöz ve Karataş & 2016 & $\begin{array}{l}\text { Granger Nedensellik } \\
\text { Analizi }\end{array}$ & $\begin{array}{l}\text { Cari açlk yabancı sermayenin nedeni } \\
\text { olup yabancı sermayeyi etkilemektedir. }\end{array}$ \\
\hline Çiftçi ve Eşmen & 2017 & VAR & $\begin{array}{l}\text { GSYH ve reel efektif döviz kurları cari } \\
\text { açı̆ga neden olmaktadır. }\end{array}$ \\
\hline Keskin & 2017 & $\begin{array}{l}\text { ARDL Sinır Testi, } \\
\text { Granger Nedensellik } \\
\text { Analizi }\end{array}$ & $\begin{array}{l}\text { Türkiye ekonomik büyüme için ithalata } \\
\text { bağımlı olup ithalatı dış finansmanla } \\
\text { (özellikle dış borçlanmayla) } \\
\text { karşılamaktadır. }\end{array}$ \\
\hline Çelik ve Erer & 2018 & $\begin{array}{l}\text { Gregory-Hansen } \\
\text { Eşbütünleşme Analizi }\end{array}$ & $\begin{array}{l}\text { Uzun dönemde bireysel emeklilik } \\
\text { fonları ile cari açı arasında negatif } \\
\text { yönlü bir ilişki bulunmaktadır, kısa } \\
\text { dönemde ise anlamlı bir ilişki } \\
\text { bulunmamaktadır. }\end{array}$ \\
\hline Kırca ve Karagöl & 2018 & Nedensellik Testleri & $\begin{array}{l}\text { Türkiye'de petrol fiyatlarından cari } \\
\text { açığa doğru tek yönlü nedensellik } \\
\text { bulunmaktadır. }\end{array}$ \\
\hline Akçelik ve Fendoğlu & 2019 & Sınır Tahmini & $\begin{array}{l}\text { Türkiye'nin kredi temerrüt takası } \\
\text { primleri ile cari açık arasında pozitif } \\
\text { bir ilișki bulunmaktadır. }\end{array}$ \\
\hline Dinçer vd. & 2019 & MARS & $\begin{array}{l}\text { Türkiye'de yüksek faiz oranları ile cari } \\
\text { açık arasında doğrusal bir ilişki } \\
\text { bulunmaktadır. }\end{array}$ \\
\hline Baş ve Kara & 2020 & ARDL Sinır Testi & $\begin{array}{l}\text { GSYH ile cari açık arasında uzun } \\
\text { dönemde, ham petrol fiyatları ile cari } \\
\text { açı arasında ise kısa dönemde anlamlı } \\
\text { bir ilișki bulunmaktadır. }\end{array}$ \\
\hline Kızıldere & 2020 & $\begin{array}{l}\text { Granger Nedensellik } \\
\text { Analizi }\end{array}$ & $\begin{array}{l}\text { Ekonomik büyüme ve enerji } \\
\text { tüketiminden cari açığa doğru } \\
\text { nedensellik bulunmaktadır. }\end{array}$ \\
\hline
\end{tabular}

\section{Kaynak: Yazarlar}

\section{Türkiye'de Cari Açığı Etkileyen Makroekonomik Faktörlerin Belirlenmesi 3.1. Veri Seti}

Türkiye'de cari açık önemli bir makroekonomik sorun olarak devam etmektedir. Bazı dönemlerde artış, bazı dönemlerde ise azalış eğilimi göstermektedir.

Türkiye'de cari açığı etkileyen faktörlerin belirlenmesine yönelik olarak Ocak 2006 ile Haziran 2018 dönem arasındaki üçer aylık veriler kullanılmıștır. Veriler, Türkiye 
Cumhuriyet Merkez Bankası Elektronik Veri Dağıtım Sistemi'nden temin edilmiştir (TCMB, 2018).

\subsection{MARS Yöntemi}

\subsubsection{MARS Algoritması ve Formülasyonu}

Literatürde bir olgunun tahmin edilmesi ya da ilgili olguya etki eden faktörlerin belirlenebilmesi için hem parametrik hem de parametrik olmayan modeller kullanılmaktadır. MARS Jerome H. Friedman tarafından geliştirilmiștir. MARS katı varsayımlara sahip olmadığı için literatürdeki mevcut yöntemlere iyi bir alternatif olarak kullanılabilmektedir (Goh vd., 2017, s. 150). MARS yöntemi bağımsız değişkenlerin bağımlı değișken üzerindeki etkisini ölçmektedir.

MARS yönteminde doğrusal olmayan ilişkiler birden fazla kırılım kullanılarak parçalı olarak doğrusal hale getirilmektedir. Ayrıca, MARS yönteminde bağımsız değişkenlerin alacağı değerlere göre bağımlı değişken üzerindeki etkisi farklı olabilmektedir. Çoklu doğrusal bağlantı sorunu MARS yönteminde herhangi bir soruna sebep olmamaktadır. (Lee ve Chen, 2005, s. 744).

Bu yöntemde klasik regresyon analizi sonucundan elde edilenin aksine, eşitlik düz bir doğru yerine parçalı bir yapıya sahip olacaktır. Kırılma noktalarına da düğüm noktası (knot) denir. Algoritma her bir açıklayıcı değişkenin kırılım noktalarına göre temel fonksiyonlar oluşturur. Bu temel fonksiyonlar ise verideki değişimi sıfır yapacak bölgeleri belirler (Friedman, 1991, s. 11). Sonuç olarak da ilk olarak veri bölgelere ayrılır ve bölgeler veriye bağlı olarak bulunur. MARS yöntemi her bir bölgeye bir regresyon eşitliği oluşturur (Lee vd., 2006, s. 1118).

MARS modelinin genel formu Eşitlik 1'de verilmiştir.

$Y_{t}=\beta_{0}+\sum_{k=1}^{K} \alpha_{k} \beta_{k}\left(X_{t}\right)+\varepsilon_{t}$

k: Düğüm sayısı

K: Temel fonksiyon sayısı

$\mathrm{X}$ : Bağımsız değişken

$\mathrm{a}_{\mathrm{k}}$ : k. temel fonksiyonun katsayısı

$\beta_{0}$ : Sabit terim

$\beta_{\mathrm{k}}\left(\mathrm{X}_{\mathrm{t}}\right)$ : t. bağımsız değişken için k. temel fonksiyon

Temel fonksiyon aşağıdaki gibi gösterilir:

$B_{m}(x)=\prod_{t=1}^{L_{m}} s_{l, m}\left(x_{v(l, m)}-k_{l, m}\right) \quad k=1,2, \ldots K$

$\mathrm{L}_{\mathrm{m}}$ : Etkileșim derecesini

$\mathrm{S}, \mathrm{m}: \varepsilon( \pm 1)$

$\mathrm{k}_{l, m}$ : Dügüm değerini

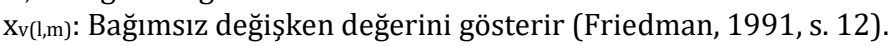

MARS yöntemi iki aşamadan oluşmaktadır. 1. aşamada bağımsız değişkenler kullanılarak olası tüm temel fonksiyonlar maksimum sayıya ulaşıncaya kadar üretilmeye devam edilir. 2. aşamada ise elde edilen en iyi model uyum iyiliği kriterlerine göre seçilir. Model tercih kriteri olarak Genelleștirilmiş Çapraz Geçerlilik (Generalized Cross Validation: GCV) $\mathrm{R}^{2}$ değeri kullanılmaktadır. GCV değerinin düşük ve $\mathrm{R}^{2}$ değerinin yüksek olması model tercih sebebidir (Sephton, 2001, s. 41). 


\subsubsection{MARS Yöntemi ile Yapılan Bazı Çalışmalar}

Finans, ekonomi ve iktisat alanında MARS yöntemi kullanılarak yapılmış çalışmalar Tablo 4'te verilmiştir.

Tablo 4: MARS Yöntemi Kullanılarak Yapılmıș Bazı Çalıșmalar

\begin{tabular}{|c|c|c|c|}
\hline Yazar & Yll & Kapsam & Sonuç \\
\hline Bolder ve Rubin & 2007 & $\mathrm{ABD}$ & $\begin{array}{l}\text { Borçlanma stratejisinin modellendiği bu çalışmada en } \\
\text { küçük kareler yöntemi, Kernel regresyon analizi ve iz } \\
\text { düşüm takip regresyonu yöntemlerinin yanı sora MARS } \\
\text { yöntemi de kullanılmıştır. Elde edilen sonuca göre, MARS } \\
\text { yönteminin tahmin başarısı daha yüksektir. }\end{array}$ \\
\hline Muzır & 2011 & Türkiye & $\begin{array}{l}\text { Kredi risk modellemesinde slklıkla kullanılan iki yöntem, } \\
\text { ikili lojistik regresyon tekniği ve yapay sinir ağlarıdır. } \\
\text { Sonuçlar incelendiğinde MARS yöntemi sonuçlarının daha } \\
\text { başarılı sonuçlar ortaya koyduğu görülmüştür. }\end{array}$ \\
\hline Tunay & 2011 & Türkiye & $\begin{array}{l}\text { Durgunlukların tahmin edilmesinde MARS yönteminin } \\
\text { performansı oldukça başarılıdır. }\end{array}$ \\
\hline Yüksel vd. & 2016 & Türkiye & $\begin{array}{l}\text { Kredi kartı kullanımı ile işsizlik arasında negatif ilişki söz } \\
\text { konusu iken, faiz oranları arasında pozitif ilişsi } \\
\text { görülmüştür. }\end{array}$ \\
\hline Kartal vd. & 2018 & Türkiye & $\begin{array}{l}\text { ABD Doları kuru, para arzı, bütçe açı̆̆ı, yabancı yatırımlar, } \\
\text { işsizlik, iç borç, ithalat, enflasyon ve cari açıtan; Euro kuru } \\
\text { ise para arzı, bütçe açı̆̆ı, cari açık, yabancı yatırımlar, ham } \\
\text { petrol ithalatı ve ihracattan etkilenmektedir. }\end{array}$ \\
\hline Zengin vd. & 2018 & Türkiye & $\begin{array}{l}\text { Cari işlemler açı̆̆ı/GSYH oranının 3,57'yi geçmesi } \\
\text { durumunda doğrudan yabancı yatırımlar azalmaktadır. }\end{array}$ \\
\hline Dinçer vd. & 2019 & Türkiye & $\begin{array}{l}\text { Yüksek faiz oranının belirleyicileri arasında enflasyon, dış } \\
\text { borçlar, bütçe açığı, cari açık ve yüksek petrol fiyatları yer } \\
\text { almaktadır. }\end{array}$ \\
\hline Kartal & 2019 & Türkiye & $\begin{array}{l}\text { Ticari kredi faizleri üzerinde en etkili faktörler sırasıyla } \\
\text { mevduat faizi, dış ticaret dengesi, merkez bankası } \\
\text { rezervleri, Dolar/TL kuru ve M2 büyüklüğü olarak } \\
\text { belirlenmiştir. }\end{array}$ \\
\hline Kartal & 2020 & Türkiye & $\begin{array}{l}\text { Kovid-19 döneminde kredi temerrüt takası primleri } \\
\text { üzerindeki en önemli etkenler } \\
\text { MSCI gelişmekte olan ülkeler endeksi, Kovid-19 kaynaklı } \\
\text { yeni ölüm sayısı, ABD Doları kuru, TCMB ağırlıklı ortalama } \\
\text { fonlama maliyeti ve oynaklık (VIX) endeksi olarak } \\
\text { belirlenmiștir. }\end{array}$ \\
\hline $\begin{array}{l}\text { Kilıç Depren ve } \\
\text { Kartal }\end{array}$ & 2020 & Türkiye & $\begin{array}{l}\text { Kredi büyüklüğü, ABD Doları kuru ve işsizlik oranı, sorunlu } \\
\text { kredi tutarı üzerinde etkili olan faktörlerdir. }\end{array}$ \\
\hline
\end{tabular}

Kaynak: Yazarlar

\subsubsection{Bağımsız Değişkenler}

Cari açı̆̆ı etkilemesi beklenen bağımsız değişkenler Literatür taraması sonucunda belirlenmiș ve Tablo 5 'te yer verilmiştir. 
Tablo 5: Bağımsız Değişkenler

\begin{tabular}{|c|c|}
\hline Bağımsız Değişken & Referanslar \\
\hline Bütçe Açı̆̆ı & $\begin{array}{l}\text { Chin ve Prasad (2003), Herwartz ve Siedenburg (2007), Barıșlk ve } \\
\text { Kesikoğlu (2010), Bayraktutan ve Demirtaş (2011), Mangır (2012), } \\
\text { Çavdar ve Karaman (2013), Türkay (2013), Agarwal (2014), Banday } \\
\text { ve Aneja (2016) }\end{array}$ \\
\hline Büyüme & $\begin{array}{l}\text { Bagnai ve Manzocchi (1999), Kandil ve Greene (2002), Malik (2010), } \\
\text { Bayraktutan ve Demirtaș (2011), Yanar ve Kerimoğlu (2011) }\end{array}$ \\
\hline $\begin{array}{l}\text { Dış Borç } \\
\text { (Kısa/Uzun Vadeli) }\end{array}$ & Yapar Saçık ve Karaçayır (2015), Keskin (2017) \\
\hline $\begin{array}{l}\text { Diş Ticaret } \\
\text { (İthalat /İhracat) }\end{array}$ & Kaur vd. (2012), Fayaz ve Sandeep (2016), Keskin (2017) \\
\hline Diș Varlıklar & Fayaz ve Sandeep (2016) \\
\hline $\begin{array}{l}\text { Döviz Kurları } \\
\text { (ABD Doları) }\end{array}$ & $\begin{array}{l}\text { Erbaykal (2007), Yılmaz ve Kaya (2007), Bitzis vd. (2008), Doğru } \\
\text { (2012), Yllmaz ve Akıncı (2012), Çiftçi (2014), Banday ve Aneja } \\
\text { (2016), Fayaz ve Sandeep (2016), Çiftçi ve Eşmen (2017) }\end{array}$ \\
\hline Döviz Kuru Endeksi & Sever ve Demir (2007) \\
\hline Enerji Giderleri/Tüketimi & Göçer (2013), Yanar ve Kerimoğlu (2011) \\
\hline Enflasyon & Banday ve Aneja (2016), Fayaz ve Sandeep (2016) \\
\hline Enerji Üretimi & Çiftçi ve Eşmen (2017) \\
\hline $\begin{array}{l}\text { Faiz Oranları (TL/ABD } \\
\text { Doları, Devlet İç } \\
\text { Borçlanma Senetleri) }\end{array}$ & $\begin{array}{l}\text { Bagnai ve Manzocchi (1999), Sever ve Demir (2007), Bitzis vd. } \\
\text { (2008), Peker ve Hotunluoğlu (2009), Yılmaz ve Akıncı (2012), } \\
\text { Kesikoğlu vd. (2013) }\end{array}$ \\
\hline GSYH & $\begin{array}{l}\text { Erbaykal (2007), Doğru (2012), Çiftçi (2014), Doğan ve Bayraç } \\
\text { (2014), Fayaz ve Sandeep (2016), Çiftçi ve Eşmen (2017), Keskin } \\
\text { (2017) }\end{array}$ \\
\hline $\begin{array}{l}\text { Kamu Kesimi Borçlanma } \\
\text { Gereği }\end{array}$ & Sever ve Demir (2007) \\
\hline Kamu Harcamaları & Doğan ve Bayraç (2014) \\
\hline $\begin{array}{l}\text { Krediler (Konut, Taşıt, } \\
\text { Tüketici) }\end{array}$ & Dücan vd. (2016) \\
\hline Milli Gelir & Yılmaz ve Akıncı (2012) \\
\hline Petrol Fiyatları & Doğru (2012), Huntington (2015), Çiftçi ve Eșmen (2017) \\
\hline Rezervler & Keskin (2017) \\
\hline Tasarruflar & Gülzar vd. (2007), Türkay (2013), Çiğdem (2017) \\
\hline Tüketim & Gülzar vd. (2007), Doğan ve Bayraç (2014) \\
\hline $\begin{array}{l}\text { Yabancı Yatırımlar } \\
\text { (Doğrudan/Portföy/Diğer) }\end{array}$ & $\begin{array}{l}\text { Bayraktutan ve Demirtaş (2011), Kaur vd. (2012), Türkay (2013), } \\
\text { Ayhan (2014), Yapar Saçık ve Karaçayır (2015), Kesgingöz ve Karataş } \\
\text { (2016), Keskin (2017) }\end{array}$ \\
\hline
\end{tabular}

Kaynak: Yazarlar

Türkiye'de cari açığı etkileyen faktörlerin belirlenebilmesi için yukarıda yer verilen değişkenler arasından bütçe dengesi, büyüme, USD TL kuru, EUR TL kuru, TÜFE, ÜFE, ihtiyaç kredisi, taşıt kredisi ve ticari kredi faizleri ile kamu harcamaları seçilmiştir. Ayrıca, TCMB net rezervlerinin de cari açık üzerinde etki oluşturabileceği düşünülerek analize dâhil edilmiștir.

\section{3. İstatistiksel Analiz ve Sonuçlar 3.3.1. Betimleyici İstatistikler}

Literatürdeki çalışmalarda kullanılmış olan değişkenler incelenerek bu çalışmada da benzer değișkenlerin kullanılmasına karar verilmiştir. Böylece analizde toplam 11 adet değişken kullanılmıştır. 
2006:3-2018:6 dönemleri arasında üçer aylık verilerin kullanılmasına karar verildiğinden, çalışmadaki gözlem sayısı 50 olarak belirlenmiştir.

MARS uygulaması R Studio programı earth paketi yardımı ile uygulanmıștır. Analizde Cari Açık/GSYH Oranındaki değişimi en iyi açıklaması beklenen modelde ikili ve üçlü etkileşimler de dâhil edilmiștir.

Şekil 2: 2006:3-2018:6 Dönemleri Arasında Cari Açı/GSYH Trendi

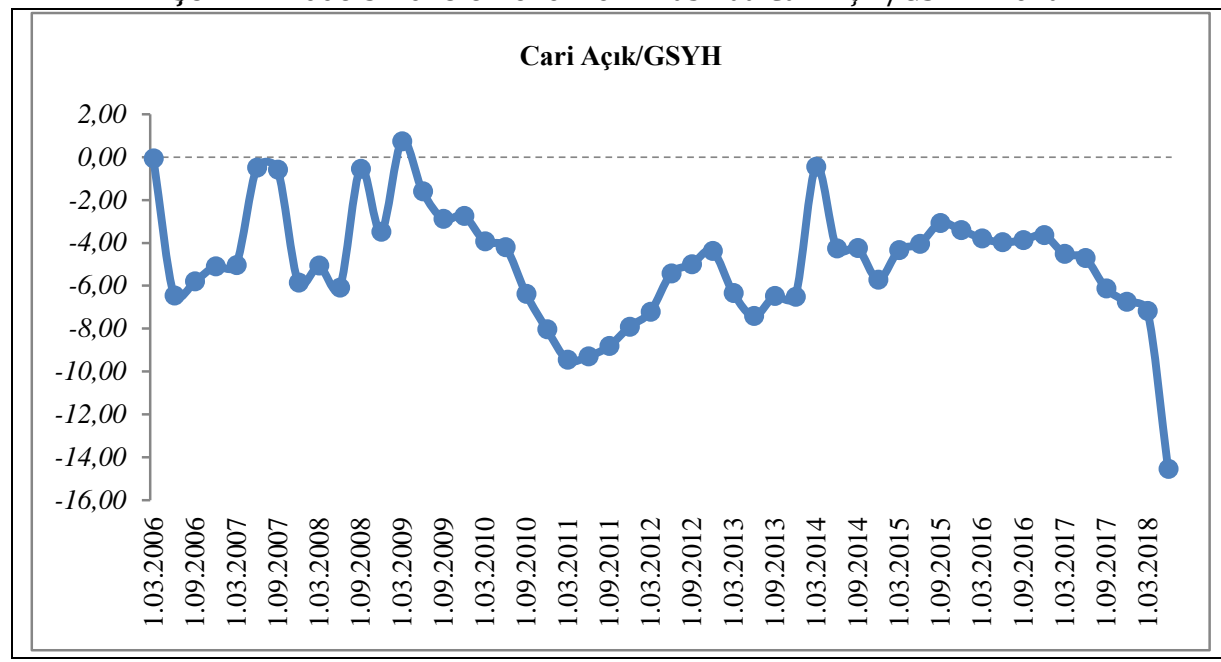

Şekil 2'de ele alınan dönemlere ait Cari Açı/GSYH oranı için trend grafiği verilmiștir. Buna göre ilgili göstergenin genellikle negatif olduğu ve 2009 yılı başında 2011 yılının ilk yarısına kadar negatif yönde büyüdüğü görülmektedir. 2011 yılı ikinci yarısından sonra ilgili gösterge azalış trendine girmiş olsa da 2014 yılının ikinci yarısından itibaren negatif tarafta durağan bir trend izlemiştir.

Çalışmada kullanılan değişkenlere ait betimleyici istatistikler Tablo 6'da verilmiștir.

Tablo 6: Betimleyici İstatistikler

\begin{tabular}{|l|l|l|l|l|l|}
\hline Bağımsız Değişken & $\begin{array}{l}\text { Gözlem } \\
\text { Sayısı }\end{array}$ & Minimum & Maksimum & Ortalama & $\begin{array}{l}\text { Standart } \\
\text { Sapma }\end{array}$ \\
\hline Cari Açık/GDP (\%) & 50 & $-14,55$ & 0,74 & $-4,93$ & 2,76 \\
\hline Bütçe Dengesi (Milyon TL) & 50 & $-30.177,37$ & $4.564,34$ & $-7.780,36$ & $7.970,98$ \\
\hline Büyüme (\%) & 50 & $-14,38$ & 11,68 & 5,33 & 4,80 \\
\hline TCMB Net Rezervler (Milyar TL) & 50 & 61,46 & 126,23 & 91,60 & 16,56 \\
\hline USD (TL Satış Kuru) & 50 & 1,19 & 4,37 & 2,09 & 0,83 \\
\hline EUR (TL Satış Kuru) & 50 & 1,60 & 5,21 & 2,62 & 0,84 \\
\hline TÜFE (\%) & 50 & $-0,32$ & 6,10 & 2,16 & 1,36 \\
\hline ÜFE (\%) & 50 & $-3,00$ & 9,42 & 2,24 & 2,59 \\
\hline TL İhtiyaç Kredi Faizi (\%) & 50 & 11,95 & 27,55 & 17,90 & 3,71 \\
\hline TL Tașit Kredi Faizi (\%) & 50 & 9,92 & 22,37 & 15,22 & 3,41 \\
\hline TL Ticari Kredi Faizi (\%) & 50 & 8,54 & 21,67 & 14,63 & 3,52 \\
\hline Kamu Harcamaları (Milyar TL) & 50 & 12,46 & 77,16 & 35,54 & 17,42 \\
\hline
\end{tabular}




\subsubsection{Cari Açı/GSYH Oranı Tahmin Modeli Bulguları}

İlgili gösterge için model seçim kriterleri ve elde edilen modeldeki temel fonksiyon sayısı Şekil 2'de verilmiştir.

Şekil 3: Cari Açık/GSYH Oranı Tahmin Modeli Çıktıları
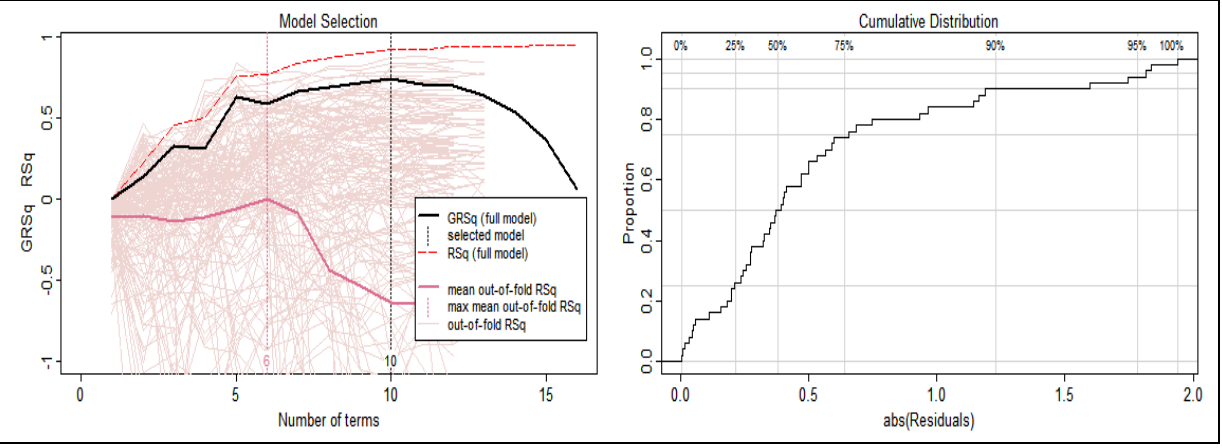

Şekil 3'e göre, toplam 16 farklı temel fonksiyon için modeller kurulmuştur. Belirleme katsayısının $\left(\mathrm{R}^{2}\right)$ en yüksek olduğu modelin 10 numaralı temel fonksiyona ait olduğu görülmüştür. Şekil 4'te ise modelde var olan hem tekil değişkenler hem de çapraz etkileşim içinde olan değişkenler için değişkenlerin kırılım noktaları verilmiștir.

Şekil 4: Cari Açık/GSYH Oranı Tahmin Modeli için Bağımsız Değişkenlerin Kırılım Noktaları
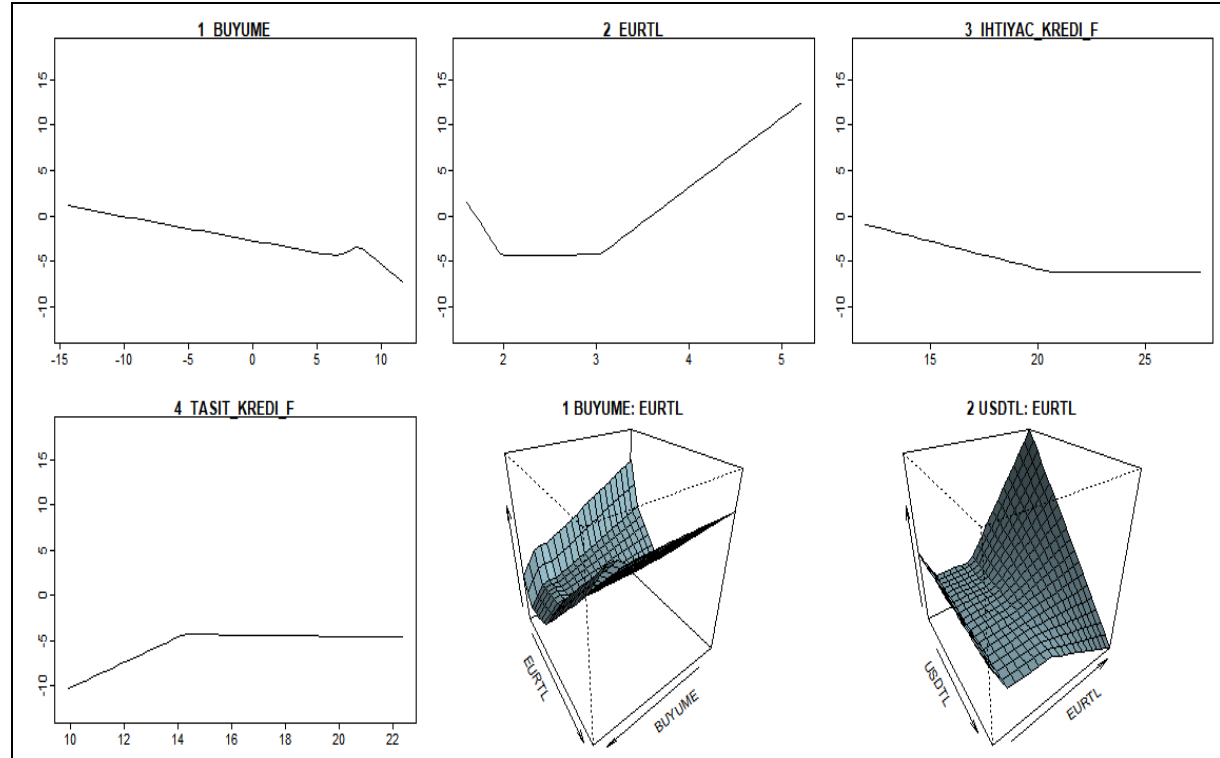

Cari Açık/GSYH oranı tahmin modelinde var olan değişkenler büyüme oranı, Euro TL kuru, ihtiyaç kredisi faiz oranı, taşıt kredisi faiz oranı, USD TL kuru ve TÜFE'dir. Şekil 
4'e göre, ihtiyaç kredisi faiz oranı ve taşıt kredisi faiz oranı 2 kırılıma, büyüme oranı ve Euro TL kurunun ise 3 kırılıma sahip olduğu görülmektedir. Ayrıca modelde büyüme oranı *Euro TL kuru, USD TL kuru, *Euro TL kuru ve Euro TL*TÜFE*taşıt kredisi faiz oranı etkileşimlerinin Cari Açı/kSSYH oranı tahmin modelinde anlamlı olduğu görülmüştür.

Model sonucunda Cari Açık/GSYH oranını etkileyen değişkenleri ve etki büyüklüklerini gösteren model çıktısı Tablo 7'de verilmiştir.

Tablo 7: Cari Açık/GSYH Tahmin Modeli Çıktısı

\begin{tabular}{|l|l|l|}
\hline Temel Fonksiyon & Değişkenler & Katsayı \\
\hline & Sabit Terim & $-23,0659$ \\
\hline BF1 & $\max (0$, Büyüme Oranı - 6,65) & 0,9986 \\
\hline BF2 & $\max (0$, Büyüme Oranı - 8,27) & $-1,9119$ \\
\hline BF3 & $\max (0$, EUR TL Kuru - 1,9736) & 15.8129 \\
\hline BF4 & $\max (0,3,0411$ - EUR TL Kuru) & 18.9151 \\
\hline BF5 & $\max (0,20.58$ - İhtiyaç Kredisi Faiz Oranı) & 0.6108 \\
\hline BF6 & $\max (0,14.26$ - Taşıt Kredisi Faiz Oranı) & -1.4270 \\
\hline BF7 & $\max (0,3,0411$ - EUR TL Kuru)* Büyüme Oranı & -0.3799 \\
\hline BF8 & $\max (0$, EUR TL Kuru - 3,0411)* USD TL Kuru & -4.5133 \\
\hline BF9 & $\max (0,3,0411$ - EUR TL Kuru) * TÜFE * Taşıt Kredisi Faiz Oranı & -0.0338 \\
\hline R2: 0,926 GCV: 1,9649 & \\
\hline
\end{tabular}

Tablo 7’ye göre, modelin açılayıcılığı (R²) 0,926 ile yüksek seviyededir. Mevcut değişkenler için hesaplanan katsayıların \%95 güven düzeyinde istatistiksel olarak anlamlı olduğu görülmüştür. Elde edilen katsayılara göre, ihtiyaç kredisi faiz oranı ve taşıt kredisi faiz oranı tek kırılıma, büyüme oranı ve EUR TL kuru ise iki kırılıma sahiptir. Bu kırılımlara ek olarak, büyüme oranı ve EUR TL kuru, Dolar TL kuru ve EUR TL kuru ikili çapraz etkileri ve EUR TL kuru, TÜFE ve taşıt kredisi faiz oranı üçlü çapraz etkisi Cari Açı/GSYH üzerinde anlamlı etkiye sahiptir. Büyüme oranının cari açı/GSYH üzerindeki tekil etkisine bakıldığında, büyüme oranının 6,65 ile 8,27 arasında olduğu durumlarda Cari Açı/GSYH azalırken, 8,27'nin üzerinde olması durumunda arttığı sonucuna ulaşılmıştır. EUR TL kurunun cari açık üzerindeki tekil etkisine bakıldığında ise, EUR TL kurunun 3,04'ün altında olması cari açı/GSYH değerini pozitif, üzerinde olması durumunda ise cari açı/GSYH değerini negatif olarak etkilediği görülmektedir. Ek olarak ihtiyaç kredisi faiz oranının 20,58'in altında, taşıt kredisi faiz oranının ise 14,26'nın altında olması Cari Açık/GSYH oranının sırasıyla negatif ve pozitif olarak etkilemektedir. Modeldeki değișkenlerin önem dereceleri incelendiğinde ise en önemli değișkenden en az önemli değişkene doğru sırasıyla büyüme oranı, EUR TL kuru, Dolar TL kuru, taşıt kredisi faiz oranı, ihtiyaç kredisi faiz oranı ve TÜFE değişkenleridir. Cari Açık/GSYH oranı tahmini için model formülasyonu Eşitlik 3'te verilmiştir.

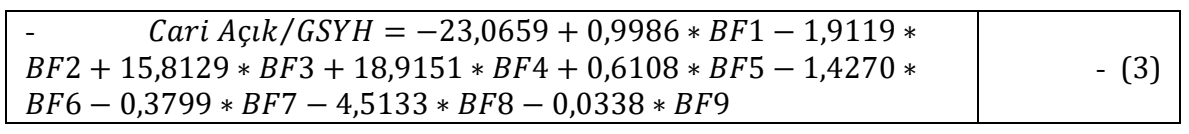

Elde edilen formülasyona göre, tahmin edilen ve gerçekleșen değerler Şekil 5'te gösterilmiștir. 
Şekil 5: Cari Açık/GSYH Oranı Tahmin Modeli için Tahmin Edilen ve Gerçekleșen Değerler

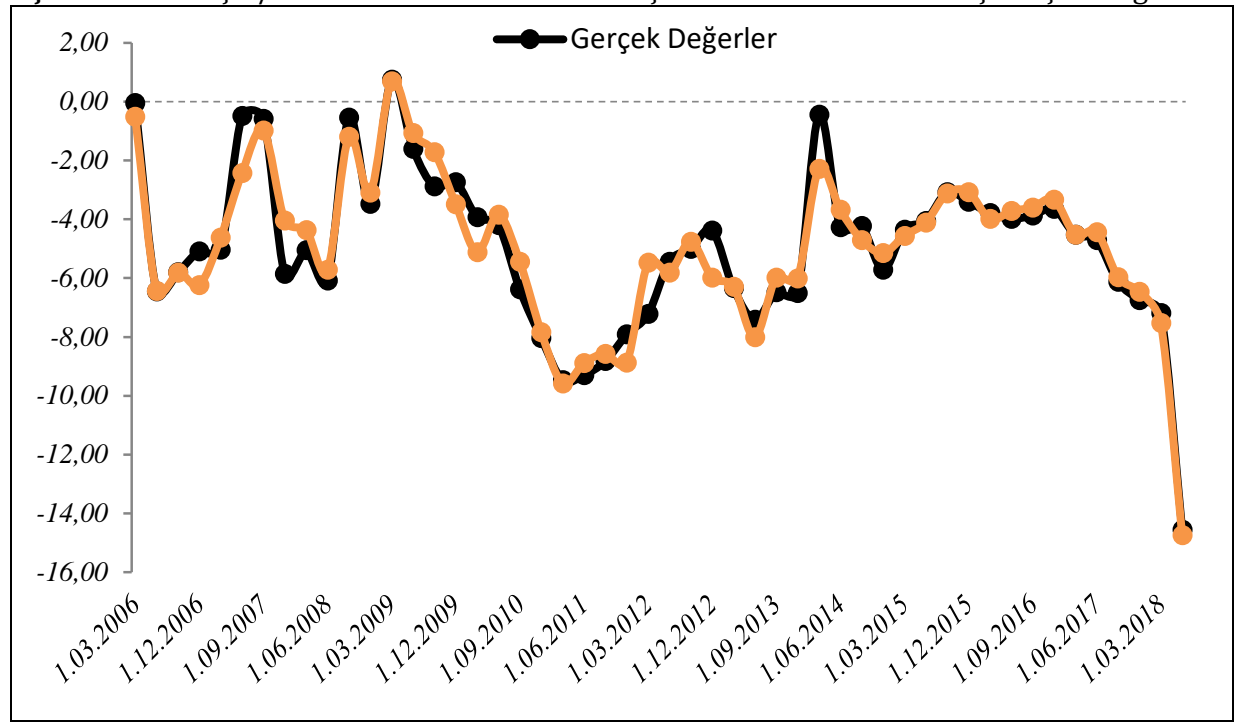

Şekil 5'e göre, MARS ile tahmin edilen değerlerin gerçek değerlerle birlikte hareket etmektedir. Fakat tahmin değerlerindeki fark dönem dönem artıp azalmaktadır.

\section{Sonuç}

Türkiye'de yaşanan 2000 ve 2001 krizleri sonrası, alınan tedbirlerin etkisi ile birlikte, Türk ekonomisi büyüme sürecine girmiştir. Bu kapsamda, birçok göstergede iyileşme yaşanmaya başlanmış, kamu borcu/GSYH oranı gibi makroekonomik göstergelerde birçok Avrupa Birliği ülkesine göre çok iyi bir konuma gelinmiştir. Bununla birlikte, bazı göstergelerde aynı derecede iyileșme sağlanmamıș veya sağlanan iyileșme son yıllarda bozulmaya başlanmıştır. Enflasyon ve faiz oranları son dönemde bozulma yaşanan makroekonomik göstergelerden bazılarıdır. Bu göstergelerin yanı sıra, cari açık Türk ekonomisi açısından geçmişten günümüze önemli bir konu olmaya devam etmektedir. Ulusal ve uluslararası ekonomik aktörler için cari açık oldukça önem atfedilen makroekonomik göstergelerden birisidir. Türkiye'nin dışa açık bir ekonomi olması nedeniyle cari açı ekonomi üzerinde ciddi etkiler oluşturmaktadır.

Türkiye'de cari açığın seyri ele alındığında 1994, 2001 ve 2009 gibi ulusal veya küresel krizlerin yaşandığı dönemlerde cari açık verilmemiş veya sınırlı seviyede oluşmuş, bunun haricindeki dönemlerde ise oldukça yüksek seviyelerde gerçekleşmiştir. 2011 yılında 74,4 milyar USD ile tarihi rekor kıran cari açık, sonrasında göreceli düşüş göstererek 2017 yılında 47,4 milyar USD, 2018 yılında ilk 8 aylık dönemde ise 29,9 milyar USD olarak gerçekleşmiştir. Cari Açı/GSYH oranına bakıldığında ise bu tabloya benzer bir seyir görülmektedir.

Türkiye'nin dışa açık bir ekonomiye sahip olması nedeniyle, cari açık ekonomi üzerinde etkiler oluşturduğundan cari açığı etkileyen makroekonomik değișkenlerin belirlenmesi önem arz etmektedir. Bu nedenle, cari açık üzerinde etki oluşturma kabiliyeti olan hükümet, ekonomiyle ilgili bakanlıklar ile düzenleyici ve denetleyici kurumların politika geliştirmesinde cari açı̆̆ı etkileyen faktörlerin bilinmesi yol gösterici olunması açısından önem taşımaktadır. Politikaların oluşturulması ve uygulanmasında 
söz konusu kurumlara yardımcı olmak ve Türkiye'de cari açı̆̆ı etkileyen faktörlerin belirlenmesi amacına yönelik olarak bu çalışma hazırlanmıştır. Cari açığı etkileyen makroekonomik faktörlerin belirlenmesi için bütçe dengesi, büyüme, USD TL kuru, EUR TL kuru, TÜFE, ÜFE, ihtiyaç kredisi, taşıt kredisi ve ticari kredi faizleri, kamu harcamaları ve TCMB net rezervleri olmak üzere 11 bağımsız değişkenin 2006/1-2018/6 dönem arasındaki üç aylık verileri MARS yöntemi ile analiz edilmiştir.

Cari Açı/kSYH değerini etkileyen faktörlerin incelendiği analiz sonucunda dokuz değişkene (sabit terim + 13 temel fonksiyon) sahip olan model tercih edilmiștir. Modelde büyüme oranı, ihtiyaç kredisi faiz oranı, taşıt kredisi faiz oranı, Euro TL kuru, Dolar TL kuru ve TÜFE değişkenlerinin cari açı/GSYH üzerinde istatistiksel olarak anlamı etkisi olduğu belirlenmiştir. Ek olarak, ilgili değişkenlerin cari açı/GSYH üzerindeki hem tekil hem de çapraz etki büyüklükleri de hesaplanmıştır. Buna göre; kur üzerinde önemi en büyük olan ilk 5 değişken büyüme oranı, EUR TL kuru, Dolar TL kuru, taşıt kredisi faiz oranı, ihtiyaç kredisi faiz oranı ve TÜFE'dir. Ayrıca elde edilen tahmin değerleri incelendiğinde, modelin açıklayıcılığının da yüksek olduğu görülmüştür. Cari açı/GSYH oranının tahmin edilmesinde MARS yönteminin oldukça başarılı sonuçlar verdiği görülmüștür.

Türkiye'de cari açığın kontrol altında tutulması, başta istikrarlı döviz kurları olmak üzere enflasyon gibi çeşitli makroekonomik değişkenler üzerinde doğrudan veya dolaylı etki oluşturmaktadır. Bu etkiler dikkate alındığında, cari açıktaki artışların önlenmesi finansal istikrar açısından önem taşımaktadır. Dolayısı ile Türkiye gibi yüksek cari açığa sahip ülkelerde, cari açığın düşük tutulması finansal istikrarın sağlanmasında oldukça önemlidir. Bu çalışmada Türkiye'de cari açığı etkileyen makroekonomik faktörler belirlenmiştir. Çalışmamızda belirtilen hususların politika yapıcılar tarafından dikkate alınması, cari açığın düşük tutulması ve bu yol ile makroekonomik ve finansal istikrarın sağlanması açılarından katkı sağlayacaktır.

Çalışmada ele alınan 11 adet bağımsız değişkenin yanı sıra, bu çalışmada dikkate alınmayan ancak araștırmacılar tarafından cari açık üzerinde etki oluşturmasının muhtemel olduğu düşünülen bağımsız değişkenler kullanılarak yeni çalışmaların yapılmasının faydalı olacağı düşünülmektedir.

\section{KAYNAKÇA}

AGARWAL, A. (2014). Current account deficit and fiscal deficit a case study of India. National Monthly Refereed Journal of Research In Commerce \& Management, 3, 20 26.

AKÇELIK, F. \& FENDOĞLU, S. (2019). Country risk premium and domestic macroeconomic fundamentals when global risk appetite slides. CBRT Research and Monetary Policy Department, No. 2019-04.

AKINCI, M. \& YILMAZ, Ö. (2016). Enflasyon-faiz oranı takası: Fisher hipotezi bağlamında Türkiye ekonomisi için dinamik en küçük kareler yöntemi. Sosyoekonomi 24(27): 33-56.

AYHAN, D. (2014). BRICS-T ülkelerine yönelik portföy yatırımlarının cari açık üzerindeki etkisi: dinamik panel veri analizi. Niğde Üniversitesi İktisadi ve İdari Bilimler Fakültesi Dergisi, 7(1), 67-75.

BAGNAI, A. \& MANZOCCHI, S. (1999). Current account reversals in developing countries: the role of fundamentals. Open Economic Review, 10, 143-163.

BANDAY, U. \& ANEJA, R. (2016). How budget deficit and current account deficit are interrelated in Indian economy. Theoretical \& Applied Economics, 23(1), 237-246. 
BARIȘIK, S. \& KESİKOĞLU, F. (2010). Makroekonomik değișken olarak bütçe açığı-cari açık ilișkisi: Gelişmekte olan piyasalar örneği. İktisat İşletme ve Finans, 25(294), 101-119.

BAŞ, G., KARA, M. (2020). Makroekonomik faktörlerin cari açlk üzerine etkisi: Türkiye için zaman serisi analizi. International Journal of Social Science Research, 9(1), 36-47.

BAYRAKTUTAN, Y. \& DEMIRTAŞ, I. (2011). Gelişmekte olan ülkelerde cari açığın belirleyicileri: panel veri analizi. Kocaeli Üniversitesi Sosyal Bilimler Enstitüsü Dergisi, 22, 1-28.

BITZIS, G., PALEOLOGOS, J. \& PAPAZOGLOU, C. (2008). The determinants of the Greek current account deficit: The EMU experience, Journal of International and Global Economic Studies. 1, 105-112.

BOLDER, J \& RUBIN, T. (2007). Optimization in a simulation setting: use of function approximation in debt strategy analysis. Bank of Canada Working Paper, 1-92.

BUSSIERE, M., FRATZSCHER M. \& MÜLLER G. J. (2004). Current account dynamics in OECD and $\mathrm{AB}$ acceding countries - an intertemporal approach. ECB Working Paper Series, 311, 1-38.

CHINN, M. \& PRASAD, E. (2003). Medium-term determinants of current accounts in industrial and developing countries: an empirical exploration. Journal of International Economics, 59, 47-76.

ÇALIŞKAN ÇAVDAR, Ş. \& KARAMAN, F. (2013). Cari açılk ve bütçe açı̆̆ını etkileyen faktörlerin nedensellik ilişkilerinin diyagram yoluyla gösterimi: Türkiye örneği. Süleyman Demirel Üniversitesi İktisadi ve İdari Bilimler Fakültesi Dergisi, 18(1), 405-416.

ÇELIKK, O. \& ERER, E. (2018). Bireysel emeklilik fonları ve cari açık arasındaki ilişki: Türkiye örneği. Ege Akademik Bakış, 18(2), 289-305.

ÇíFTÇİ, N. (2014). Türkiye'de cari açık, reel döviz kuru ve ekonomik büyüme arasındaki ilişkiler: eşbütünleșme analizi, Anadolu Üniversitesi Sosyal Bilimler Dergisi, 14, 129-142.

ÇífTÇİ, N. \& EŞMEN, M. (2017). Türkiye'de cari açı̆̆ı belirleyen faktörler ve cari açığı azaltmada alternatif enerji kaynaklarının rolü: VAR modeli. Bilecik Şeyh Edebali Üniversitesi Sosyal Bilimler Enstitüsü Dergisi, 2(1), 83-110.

Çí̆GEM, G. (2017). Investigation of the relationship between current account deficit and savings in MENA economies: an empirical approach. International Journal of Economics and Reserach, 8(3), 1-6.

DINCCER, H., YÜKSEL, S. \& KARTAL, M. T. (2019). The role of bank interest rate in the competitive emerging markets to provide financial and economic stability. Ekonomi, İşletme ve Maliye Araştırmaları Dergisi, 1(2), 103-120.

DOĞAN, E. \& BAYRAÇ, H.N. (2014). Türkiye'de cari açık sorunu üzerine mikro temelli bir yaklaşım. Eskişehir Osmangazi Üniversitesi Sosyal Bilimler Dergisi, 15(2), 97 124.

DOĞRU, B. (2012). ABD ve AB bölgesindeki bir finansal krizin Türkiye'ye etkileri, cari açık üzerine bir uygulama. Dumlupınar Üniversitesi Sosyal Bilimler Dergisi, 33, 113128.

DÜCAN, E., POLAT, M.A. \& BALCIOĞLU, E. (2016). Tüketim toplumu örneği olarak Türkiye'nin cari açık ve tüketici kredileri ilişkisi. Siyaset, Ekonomi ve Yönetim Araștırmaları Dergisi, 4(1), 161-188.

Dünya Bankası. (2018). Current account balance (\% of GDP). Erişim tarihi:

29.11.2018, https://data.worldbank.org/indicator/BN.CAB.XOKA.GD.ZS

EĞILMEZ, M. \& KUMCU, E. (2004). Ekonomi politikası, teori ve Türkiye uygulaması. İstanbul: Remzi Kitabevi. 
ERBAYKAL, E. (2007). Türkiye'de ekonomik büyüme ve döviz kuru cari açık üzerinde etkili midir? Bir nedensellik analizi. ZKÜ Sosyal Bilimler Dergisi, 3, 81-88.

EŞiYOK, B. A. (2012). Türkiye ekonomisinde cari açık sorunu ve nedenleri. Finans Politik \& Ekonomik Yorumlar, 49(569), 63-85.

FAYAZ, M. \& SANDEEP, K.B. (2016). Trends, patterns and determinants of Indian current account deficit. Applied Econometrics and International Development, 16(1), 167 186.

FRIEDMAN, J. (1991). Multivariate Adaptive Regression Splines. The Annals of Statistics, 19, 1-141.GOH, A. T. C., ZHANG, Y., ZHANG, R., ZHANG, W. \& XIAO, Y. (2017). Evaluating Stability of Underground Entry-Type Excavations Using Multivariate Adaptive Regression Splines and Logistic Regression. Tunnelling and Underground Space Technology, 70, 148-154.

GÖÇER, İ. (2013). Türkiye'de cari açığın nedenleri, finansman kalitesi ve sürdürülebilirliği: ekonometrik bir analiz. Eskişehir Osmangazi Üniversitesi İIBF Dergisi, 8, 213-242.

GÜLZAR, S., XIAO, H. \& YAJIE, W. (2007). The current account balance of Pakistan 1972- 2005: a cointegrasyon. Information Technology Journal, 6, 664-671.

HAN, X. \& YONG, Y. (2020). The relationship and trend of current account and budget deficit: a case study of China. Academic Journal of Business \& Management, 2(4), 129-134.

HERWARTZ, H. \& SIEDENBURG, F. (2007). Determinants of current account imbalances in 16 OECD countries: an out-of-sample perspective. Review of World Economics, 143, 349-374.

HUNTINGTON, H. (2015). Crude oil trade and current account deficits. Energy Economics, 50, 70-79.

İMROHOROĞLU, A. \& ZHAO, K. (2020). Household saving, financial constraints, and the current account in China. International Economic Review, 61(1), 71-103.

KANDIL, M. \& GREENE J. (2002). The impact of cyclical factors on the U.S. balance of payments. IMF Working Paper, 45, 1-43.

KARTAL, M. T. (2019). Türkiye'de kredi faizlerini etkileyen faktörlerin belirlenmesi: MARS yöntemiyle bir analiz. Bankacılar Dergisi, 108, 24-41.

KARTAL, M. T. (2020). The behavior of sovereign credit default swaps (CDS) spread: evidence from Turkey with the effect of Covid-19 pandemic. Quantitative Finance and Economics, 4(3), 489-502.

KARTAL, M. T., KILIÇ DEPREN, S. \& DEPREN, Ö. (2018). Döviz kurlarını etkileyen makroekonomik faktörlerin belirlenmesi: Türkiye'de ABD Doları ve Euro kurları üzerine ekonometrik bir inceleme. MANAS Journal of Social Studies, 7(1), 209-229.

KAUR, M., YADAV, S. S. \& GAUTAM, V. (2012). Foreign direct investment and current account deficit-a causality analysis in context of India. Journal of International Business and Economy, 13(2), 85-106.

KESIKOĞLU, F., YILDIRIM, E. \& ÇEŞTEPE, H. (2013). Cari açığın belirleyicileri: 28 OECD ülkesi için panel VAR analizi. AİB̈̈ - IIBF Ekonomik ve Sosyal Araştırmalar Dergisi, 9, 15-34.

KESGINGÖZ, H. \& KARATAȘ, A. R. (2016). Yabancı sermaye yatırımları ile cari işlemler açı̆̆ ilişkisi ve cari işlemler açığı için politika önerileri. İnsan ve Toplum Bilimleri Araștırmaları Dergisi, 5(3), 597-610.

KESKIN, A. (2017). Türkiye'de cari açık sorunu ve açı̆̆ın finansman yapısı: 19892015 Dönem analizi. Amme Idaresi Dergisi, 50(3), 89-125.

KILIÇ DEPREN, S. \& KARTAL, M. T. (2020). Prediction on the Volume of NonPerforming Loans (NPL) in Turkey using Multivariate Adaptive Regression Splines (MARS) Approach. International Journal of Finance and Economics, In Press. 
KIRCA, M. \& KARAGÖL, V. (2018). Türkiye'de petrol fiyatları ve cari açık arasındaki simetrik ve asimetrik nedensellik ilişkilerinin analizi. Akademik Araştırmalar ve Çalışmalar Dergisi, 10(18), 59-71.

KIZILDERE, C. (2020). Türkiye'de cari açık sorununun enerji tüketimi ve ekonomik büyüme açısından değerlendirilmesi: Ampirik bir analiz. Business \& Management Studies: An International Journal, 8(2), 2121-2139.

LEE, T. S. \& CHEN, I. F. (2005). A Two-Stage Hybrid Credit Scoring Model Using Artificial Neural Networks and Multivariate Adaptive Regression Splines. Expert Systems with Applications, 28, 743-752.

LEE, T. S., CHIU, C. C., CHOU, Y. C. \& LU, C. J. (2006). Mining the Customer Credit Using Classification and Regression Tree and Multivariate Adaptive Regression Splines. Computational Statistics \& Data Analysis, 50, 1113-1130.

LIN, S. X. \& KUEH, J. (2019). Determinants of current account balance in Six ASEAN countries: a panel analysis approach. International Journal of Economics and Finance, 11(7), 129-129.

LONGE, A. E., ADELOKUN, O. O. \& OMITOGUN, O. (2018). The current account and oil price fluctuations nexus in Nigeria. Journal of Competitiveness, 10(2), 118-131.

MANGIR, F. (2012). Türkiye için ikiz açlklar hipotezi testi (1980-2011). Niğde Üniversitesi IIBF Dergisi, 5, 136-149.

MALIK, S., CHAUDHRY, I. S., SHEIKH, M. R. \& FAROOQI, F. S. (2010). Tourism, economic growth and current account deficit in Pakistan: evidence from co-integration and causal analysis. European Journal of Economics, Finance and Administrative Sciences, 22, 21-31.

MUZIR, E. (2011). Basel II düzenlemeleri doğrultusunda kredi riski analizi ve ölçümü: geleneksel ekonometrik modellerin yapay sinir ağları ve MARS modelleriyle karşılaștırılmasına yönelik ampirik bir çalışma (Yayınlanmamıș Doktora Tezi). İstanbul Üniversitesi Sosyal Bilimler Enstitüsü, İstanbul.

NASON, J. M. \& ROGERS J. H. (1999). Investment and the current account in the short run and the long run. board of governors of the Federal Reserve System.

International Finance Discussion Papers, 647, 1-59.

PEKER, O. \& HOTUNLUOĞLU, H. (2009). Türkiye'de cari açığının nedenlerinin ekonometrik analizi. Atatürk Üniversitesi I.I.I.B.F. Dergisi, 3, 221-237.

SAÇIK, S. Y. \& ALAGÖZ, M. (2010). Türkiye'de cari işlemler açığı sorunu ve borçlanma ile ilişkisi. Ekonomi Bilimleri Dergisi, 2(2), 113-120.

SEPHTON, P. (2001). Forecasting Recessions: Can We Do Better on MARS?

Review Federal Reserve Bank of Saint Louis, 83(2), 39-49.SEVER, E. \& DEMIR, M. (2007). Türkiye'de bütçe açığı ile cari açı arasındaki ilişkilerin VAR analizi ile incelenmesi. Eskişehir Osmangazi Üniversitesi IIBF Dergisi, 2(1), 47-63.

SOYSA, N., PALLEGEDARA, A. \& DEEGAHAWATURE, D. (2019). Effects of global crude oil price fluctuation on the current account balance in Sri Lanka. In Sri Lanka Economic Research Conference (SLERC), 201-204.

TCMB. (2018). Ödemeler dengesi istatistikleri. Erişim tarihi: 29.11.2018, http://www.tcmb.gov.tr/wps/wcm/connect/TR/TCMB+TR/Main+Menu/Istatistikler/Ode meler+Dengesi+ve+Ilgili+Istatistikler/Odemeler+Dengesi+Istatistikleri

TCMB. (2020). Cari açık ve kırılımına ilişkin veriler. Erişim tarihi: 13.07.2020, https://evds2.tcmb.gov.tr/index.php?/evds/serieMarket/collapse_18/5122/DataGroup/tu rkish/bie odeayrsunum6.

TUNAY, K. B. (2011). Türkiye'de durgunlukların MARS yöntemi ile tahmini ve kestirimi. Marmara Üniversitesi I.I.I.B.F. Dergisi, 30, 71-91.

TÜRKAY, H. (2013). Türkiye'de cari açık, bütçe açığı ve yatırım-tasarruf açığı ilişkisi. Cumhuriyet Üniversitesi İktisadi ve İdari Bilimler Dergisi, 14(2), 253-269. 
YANAR, R. \& KERIMOĞLU, G. (2011). Türkiye'de enerji tüketimi, ekonomik büyüme ve cari açık ilişkisi. Ekonomi Bilimleri Dergisi, 3(2), 191-201.

YAPAR SAÇIK, S. \& KARAÇAYIR, E. (2015). Türkiye'de cari işlemler hesabının finansmanı: ARDL sınır testi yaklaşımı. Selçuk Üniversitesi Sosyal Bilimler Enstitüsü Dergisi, 33, 155-166.

YILMAZ, Ö. \& AKINCI, M. (2012). Türkiye'de cari açıkların belirleyicileri: bir zaman serisi analizi. TiSK Akademi, 7, 54-83.

YILMAZ, Ö. \& KAYA, V. (2007). İhracat, ithalat ve reel döviz kuru ilişkisi: Türkiye için bir VAR modeli. Iktisat İşletme ve Finans Dergisi, 22, 69 - 84.

YÜKSEL, S., ZENGINN, S. \& KARTAL, M. T. (2016). Identifying the macroeconomic factors influencing credit card usage in Turkey by using MARS method. China-USA Business Review, 15(12), 611-615.

ZENGIN, S., YÜKSEL, S. \& KARTAL, M. T. (2018). Understanding the factors that affect foreign direct investment in Turkey by using MARS method. Finansal Araştırmalar ve Çalışmalar Dergisi, 10(18), 177-192.

\section{Summary}

In Turkey, after 2002, there have been improvements in many economic indicators, including in particular the reduction of high inflation and interest rates. Nevertheless, problems such as inflation, interest, and unemployment are in double digits are still existing. On the other hand, there are fluctuations in exchange rates and this leads to fragility in the economy and negativity in economic actors. In addition, Turkey's current account deficit continues to be the soft belly for a long time. When the development of the current account deficit in Turkey, it is observed that there is a negative trend. The current account deficit in Turkey has significantly increased after 2002 and reached a record high in 2011 with 74.4 billion USD. On the other hand, in 1994, 2001 and 2009, when the national and global crises were experienced, the current account deficit improved significantly compared to previous years. Different actions have been taken by the management of the economy to reduce the current account deficit in Turkey. These actions from time to time reduce the current account deficit and from time to time increase it. In order to be solved for the current account deficit in a permanent manner in Turkey, it is a necessity to perform on-site interventions for the current account deficit. In this study, it is aimed to determine the macroeconomic factors affecting the current account deficit in Turkey and thus help to develop a policy to keep the current account deficit under control.

Data is obtained from the Central Bank of the Turkish Republic website using electronic data sharing system. As for determining the factors affecting the current account deficit in Turkey, the dataset with 50 observations, which is based on the 3-month period between January 2006 and June 2018, is used. The variables used in the literature are examined and it is decided to use similar variables in this study. Thus, a total of 11 independent variables are used in the analysis, which are the growth rate, EUR/TL exchange rate, the USD/TL exchange rate, the car loan interest rate, the general purpose loan interest rate and the (Consumer Price Index) CPI. Current account deficit / Gross Domestic Products (GDP) is used as the dependent variable. The analysis is conducted using $R$ Studio with "earth" package, two and three-way interactions are included in the model to increase the model accuracy. The model has been tested with 16 different basis functions, and the model that has the highest $R^{2}$ is found to the model with 10 basis functions. In addition, significant thresholds which have an important effect on current account deficit / GDP for both single and interactions are also calculated. 
The accuracy $\left(R^{2}\right)$ of the model is at an acceptable level with 0.926 and the effects of all the variables used in the model have statistically significant. According to the results, interest rates of general purpose loan and car loan have only one threshold while growth rate and EUR/TL exchange rate have two thresholds. However, two-way interaction effects of growth rate and EUR TL exchange rate, USD/TL exchange rate and EUR/TL exchange rate and three-way interaction effects of EUR/TL exchange rate, CPI and car loan interest rate have considerable impacts on current account deficit / GDP.

When the effect of growth rate on current account deficit / GDP is examined, it is concluded that if the growth rate is between 6.65 and 8.27, the current deficit / GDP decreases and it increases if the growth rate is above 8.27. The EUR/TL exchange rate has a negative effect on the current account deficit / GDP if it is above 3.04 while the EUR/TL exchange rate below 3.04 affects the current account deficit / GDP value positively. In addition, the interest rate below 20.58 affects the current account deficit / GDP value negatively while the car loan interest rate below 14.26 affects it positively.

When the variables in the model are ordered from the most important to least, the variables are the growth rate, EUR/TL exchange rate, the USD/TL exchange rate, the car loan interest rate, the general purpose loan interest rate, and the CPI.

Keeping the current account deficit under control in Turkey constitutes a direct or indirect impacts on macroeconomic variables such as exchange rates and inflation. Once these impacts are taken into consideration, it is important for financial stability to prevent increases in the current account deficit.

Considering the issues mentioned in this study and keeping the current account deficit at a lower level will contribute to maintain macroeconomic and financial stability. 